\title{
2 \\ Three Sectors, One Public Purpose
}

\section{Peter Shergold}

The conveners of the workshop from which the chapters in this volume are drawn invited Professor Peter Shergold AC, Chancellor of Western Sydney University, to give an opening address contextualising the importance of learning to work across sectoral boundaries towards solutions to pressing social problems. This he did with characteristic verve and deep insight. The chapter that follows is from the approved text of Professor Shergold's address. This can also be viewed on the ANZSOG YouTube channel at: youtube.com $/$ watch?v=bUskUOX4_To.

I am delighted to have been afforded the opportunity to speak at this workshop on cross-sector working. I speak to you as an enthusiast, albeit a person chastened by the experience of how difficult it can be to turn the easy rhetoric of reciprocated trust and mutual respect into substantive reality. My passion is largely undimmed by cautious realism. The institutions of the public service can workand on occasions do work - in full partnership with the private and community sectors to design and deliver the goals of democratic government. More often, however, the potential to collaborate for public purpose has been sold short. My address is a heartfelt plea for greater ambition and more courage. 
In writing on this subject, I have learned to utilise the language of public management. I have spoken of the advantages of network governance. That term should not be limited to the commissioning of third-party agents to deliver services to citizens (predominantly, although not exclusively, by contracting not-for-profit organisations to implement government programs in areas such as aged, disability, health and community care, and training or employment services). There is great value in the mechanism of public-private partnerships, although the contractual conditions that are agreed in particular cases need careful attention. There are benefits - too often constrained by the bureaucratic processes of outsourcing - to creating a contestable market in which citizens can be given greater choice, flexibility and control, including through consumer-directed care (CDC). These developments foreshadow the potential creation of a public economy stretching far beyond the institutions of the public service.

There is much more significant advantage if public administrators can engage commercial and social enterprises in the co-design and co-production of the programs that make manifest the policy objectives of government. Performance-based outcomes can allow business and community organisations to have a greater chance to be rewarded for results rather than paid for process. There is a need for tenders that encourage providers to pursue agreed outcomes in their own way.

I emphasise that my belief in cross-sectoral working is not the consequence of a sudden late-age epiphany. Rather, my views reflect a long personal journey. It began before I joined the Australian Public Service (APS) in the mid 1980s, when, as an academic, I undertook with Dr Loucas Nicolaou a report for the Department of Immigration. It was based on detailed focus group discussions with ethnic communities. Its title, taken from the pithy comment of a participant, became our unsubtle message: Why Don't They Ask Us? We're not dumb. We argued that refugee and migrant groups should be given the chance to contribute to the arrangement of the settlement services they received. Ironically, the things that most organisations wanted (a typewriter, a Gestetner printing machine, a community meeting room or access to a trained interpreter) were mostly modest.

I kept that faith in community wisdom and individual capacity through my two decades as a public servant, from the year I established the Office of Multicultural Affairs in 1987 (for Prime Minister Bob Hawke) 
to the time I spent as Secretary of the Department of the Prime Minister and Cabinet from 2002 to 2007 (for Prime Minister John Howard). The collaborative impulse inspired me when I had responsibility, as head of the Department of Education, Employment and Workplace Relations in 1997, for the oversight of that bold Commonwealth experiment in cross-sectoral working, the Job Network (from 2009, also known as Job Services Australia; and from 2015, jobactive). In that capacity, I learned the language of market testing and benchmarking. I am relieved that I eschewed dim-witted references to the so-called 'yellow pages' test (if the private sector could be shown to offer a service then the public service should vacate the space). Unfortunately, the end result of outsourcing labour market programs has been at most a revolution half-fulfilled: jobseekers are still given too little real choice and providers afforded too little real freedom to innovate.

But my faith remains strong. I said in my valedictory speech on departure from the public service in 2007 that public and not-forprofit organisations needed to work together to deliver government policy. Almost eight years on and that perspective still informs the report I have recently handed to the Commonwealth Government on the lessons to be learned from the manifold mistakes that characterised the execution of the Home Insulation Program (Shergold 2016). In that instance, the benefits of cross-sector working were sacrificed on the altar of implementation speed, with tragic consequences. I am persuaded that serving the public purpose needs to be a shared endeavour: 'Whilst I love the making of public policy, and I believe that the APS contributes mightily to that effort in extraordinarily beneficial ways, I am increasingly persuaded that it is far too important to be left to governments and public services' (Shergold 2012: 63).

So why has the path to effective cross-sectoral collaboration been so slow, circuitous and erratic? Partly because working together calls for considerable emotional intelligence. It is often hard to imagine the world from the perspective of other parties. Most successes bear testimony to the leadership of particular committed individuals who have exhibited the capacity to stand in the shoes of their counterparts and see challenges through their eyes.

Partly it is because the rhetoric of partnership has actually been too modest. Cross-sectoral working in the public interest has the potential not just to improve cost-effectiveness and 'customer' service, but also 
to widen and reinvigorate the participatory nature of democratic governance. It offers the potential for adaptive government. The concept refers to those circumstances in which collaborationdriven by trials and subject to errors - allows public administration to become more agile and experimental.

In general, cross-sector working has been marked by failures of implementation, nerve and imagination. That is not a cause for despair. It is feasible to learn the lessons from both grievous mistakes and modest successes and to re-envision collaborative endeavour. At least that's the real-world experience that I'm trying to benefit from .... and I have the advantage of being able to draw my insights from a bulging volume of personal errors.

So let me, Star Trek fashion, split my infinitives 'to boldly go where no man has gone before' (or, after Star Trek VI, in a bow to genderneutral language, to go where no one has gone before). Here, I suggest, is what democratic governance may look like in the immediate years ahead; these 'are its voyages and its adventures'.

In the future, elected governments, as today, will set the public interest and answer to the electorate at the ballot box for the decisions they make in pursuit of their agenda. They will continue to establish policy goals and budgetary parameters. Subject to Parliamentary support and judicial interpretation, governments will determine the services and regulatory environment that give effect to their choices. Public services, for their part, will still be expected to serve faithfully successive governments, providing robust advice on the complex and wicked problems of public policy and overseeing the implementation of the programs that give the policy effect. So far, same old, same old Westminster.

What changes in the new world is that public service agencies will no longer aspire to wield monopoly control over the advice that governments receive. Nor will they seek to use their situational authority to command and control the manner in which contracted organisations deliver programs. Rather, public servants will judge their leadership by the extent to which they have acted as stewards of public resources and facilitators of cross-sectoral collaboration. They will actively involve and commission others to help design government policies and to plan the legislative and administrative architecture that frames their implementation. 
Commissioned organisations will be viewed not merely as agents of government but also as partners in government, working collaboratively with public service departments to create and maintain a public economy. Providers will have far greater control over how services are delivered. They will be able to tailor programs to place and community. They will be encouraged to empower citizens as consumers to exercise greater control over which services they require and which providers (public or private) they prefer to deliver them. The ethos of impact investment will be embraced, allowing non-governmental partners (such as community organisations) to raise funds in the private market, and to pay a return to those who offer debt or equity-but only if they can successfully deliver the public outcomes that have been agreed. The introduction of social benefit bonds in New South Wales, and soon in South Australia and New Zealand, provides a good example of how public, private and community organisations can work together not just to design but also to fund government programs. I set out the broad parameters of cross-sectoral collaboration in my 2013 report for the Victorian Minister for Community Services: 'The collaborative relationship between the public service agencies and non-government organisations that together deliver government programs should be founded on appreciation of the constraints under which all sides operate, mutual respect, reciprocated trust, authentic consultation, and a shared recognition of common purpose' (Shergold 2013: 17).

In short, the driving ethos of public servants who apolitically serve the government of the day will be to expedite greater levels of participation in the processes of democratic governance. They will encourage private and community providers as well as citizen users to have greater influence on decision-making. Some of these developments are already occurring on the exciting peripheries of public administration. The question is: what do government agencies need to do to transform the core of their institutional being? I suggest four things.

First, public services must look outwards. By being more open to experience beyond the public sector, they can significantly improve the creativity and productivity of public administration. This is not intended to deprecate in any measure the considerable vocational skills required of senior public servants working in a world of contested and ambiguous political power. They must continue to shoulder the necessary burden of public scrutiny, responsibility, answerability and accountability. 
In this most fundamental sense, public servants must remain public servants. But they also need to recognise that the world of market contest (whether directed to sustaining shareholder profit or to winning the philanthropic dollar) drives competitive impulses in a manner that can enhance public benefits. Public services are not the only institutional reflections of officialdom. Many large corporate and charitable ventures have bureaucratic structures of vertical hierarchy and horizontal demarcation that match the organisational rigidity of any department of state. The difference is that big businesses and big charities face constant pressure from disruptive innovation in the form of new products, new services, new distribution channels, new competitors and the evolving expectations of their customers or donors.

For that reason, they tend to set far higher store on assessing and managing risk appetite and project implementation. Even the largest and most traditional of private or community organisations exhibits a form of structured entrepreneurship rarely seen in public sector agencies. Their market experience can teach the public sector to be more adaptive: operationalising new ideas early, piloting and evaluating new approaches and, on that basis, failing quickly, adapting progressively or scaling up methodically.

Second, public services must embrace partnership. There are at least two aspects to this entreaty. Public services need to recognise the value that can be added to policy development and program design by universities, think tanks, research institutes and consultancy companies. Too often public servants direct their research capabilities to identifying policy-based evidence to justify a political outcome that has already been decided. That is clever but unsatisfactory. There is far greater merit in actively working with collaborators in pursuit of evidence-based policy with which to influence political decisions. Of course, public servants must continue to apply their conceptual and analytical skills, not just to articulate the research in a manner that is relevant to government priorities, but also to translate academic findings into the sort of practical knowledge that governments can properly comprehend and apply.

At the same time, the considerable frontline experience that businesses and not-for-profit organisations possess needs to be incorporated into the design of government programs. I have sought to walk my talk. 
In Western Australia, I set up and chaired the Partnership Forum that brings together the state's directors-general and community sector chief executive officers (CEOs). As Coordinator-General for Refugee Resettlement in New South Wales, I have established a Joint Working Group of senior public servants and community leaders to work together in identifying policy gaps and how they can best be addressed. These experiences persuade me that contracted organisations can add significant value to consideration of the structures by which government payments and services are delivered. Of course, both sides have to be aware of and carefully manage the probity issues involving conflicts of pecuniary interest around government tendering. Incidentally, providers are not the only ones who can contribute to collaborative design. Program managers too often underappreciate the first-hand experience of those more junior public servants who are actively engaged with the public. As a consequence, the considerable creativity of frontline staff is spent finding work-arounds to highly prescriptive administrative guidelines that reduce the common-sense autonomy they can exercise to improve customer service. There is a need for policy to be designed from the bottom up and power devolved from the top down.

Third, public services must empower citizens. It is apparent, to choose the most egregious example, that too much of the assistance directed to citizens in need (payments, concessions, subsidies, programs and services) is provided in ways that can perpetuate their sense of social exclusion and dependence. A safety net to catch people when they fall can be very difficult for them to climb out of. If public servants treat people as recipients or cases to be managed, many, not surprisingly, will learn helplessness.

That is the significance of the recent government emphasis on consumerdirected care, particularly in the delivery of services to those with a disability or in the provision of assistance to senior citizens living at home. Cross-sectoral working should be driven as much as possible by the preferences of those receiving public support. The fact that both government agencies and contracted community providers may find it financially more secure and administratively more convenient to agree on an inflexible block grant approach to service delivery does not mean it is in the best interests of the recipient. Collaboration between the public contractor and the private/community provider should not become an excuse for mutual self-interest. The driving principles 
must be choice and contestability. Citizens need to be encouraged and assisted to make decisions for themselves. The danger is that public servants will oversight too careful a rendition of CDC, in which choices for citizens are carefully limited; it will be far better to widen ambitions and put citizens firmly in control of the choices that they wish to make for themselves: 'The future of assertive citizenship lies in finding collaborative approaches to engage individuals in building a new form of public economy ... They can be encouraged to become state actors in a more networked form of governance' (Shergold 2014: 70).

Fourth, public servants must continue to extol public purpose. The concept of public service, if not its institutional manifestation, remains profoundly persuasive. As a nation, we face intimidating challenges. Too few Australians trust politicians (thankfully, public servants poll rather better). Too few young Australians set high store by the value of democracy as a form of government.

Yet the picture is not unremittingly bleak. Many Australians, given half a chance, will willingly volunteer their time to the pursuit of public purpose: think, as instances, of the thousands of readers who voluntarily correct digitised newspaper text for the National Library of Australia as part of its Trove project; or of the hundreds of people eager to attend the annual GovHack events and design new apps for the benefit of the public. This goodwill and enthusiasm can be harnessed. As the new Digital Transformation Office recognises, there are increasing opportunities to use deliberative techniques of online democracy to engage the public in policy discussions. The importance that the new Prime Minister, Malcolm Turnbull, places on this potential may perhaps be gauged by the fact that the office has now become part of the Prime Minister's portfolio.

So what do these four pillars of cross-sector working mean for the structure of public administration? They require senior public servants to embrace new forms of leadership. The demands of public administration have increased and have become more complex and the exercise of authority needs to be more sensitive and subtle. It will require the leadership of facilitation. Success will be judged by the extent to which cross-sector working can be fully exploited for public benefit. The old-style modes of behaviour were based on controlling, contracting, consulting and communicating. In the new world, the dominant form of authority will be collaborating, co-designing, coproducing $\ldots$ and communicating: 'Genuine collaboration ... 
requires public servants who, with eyes wide open, can exert the qualities of leadership necessary to forsake the simplicity of control for the complexity of influence' (Shergold 2008: 21).

Success will depend on public servants being appropriately trained in the skills of negotiation, discussion, empathetic listening and openness. It will require them actively to encourage innovative forms of cross-sectoral partnership, founded on citizen engagement and driven by the challenge of applying scarce public resources most effectively to the achievement of public good.

I do not underestimate how difficult it will be to create this new form of governance. It will almost certainly require greater levels of political authority than have been exhibited until now. Australian political leaders, often with good reason, do not naturally embrace sweeping new approaches such as the 'third way' or 'big society'. Fortunately, for sound pragmatic reasons, the future of public administration is already taking shape. Both Commonwealth and state governments, to varying extents, are introducing customer service improvements, performance-based commissioning, consumer-directed care, placebased funding and public impact investing. At the heart of these diverse activities lies cross-sector working. Unfortunately, the new approaches are largely hidden from public view. Perhaps we just need to be able to tell the story of public innovation clearly? For public servants, just as much as for politicians, a clear and persuasive narrative of purpose is important. 'Adaptive government' might serve as a title.

I very much hope that this important workshop can contribute to that task.

\section{References}

Shergold, P. 2008. 'Governing through collaboration.' In Collaborative Governance: A new era of public policy in Australia?, eds J. O'Flynn and J. Wanna, 13-22. Canberra: ANU E Press.

Shergold, P. 2012. 'In the national interest.' In With the Benefit of Hindsight: Valedictory reflections from departmental secretaries 2004-11, eds J. Wanna, S. Vincent and A. Podger, 53-64. Canberra: ANU E Press. 
Shergold, P. 2013. Service sector reform: A roadmap for community and human services reform. Report for the Victorian Minister for Community Services. Victorian Government, Melbourne.

Shergold, P. 2014. 'Assertive citizenship.' In Connected Government Compendium, ed. J. Dan, 66-75. Sydney: Telstra.

Shergold, P. 2016. Learning from failure: Why large government policy initiatives have gone so badly wrong in the past and how the chances of success in the future can be improved. Report, 5 February. Australian Public Service Commission, Canberra. Available from: www.apsc. gov.au/publications-and-media/current-publications/learningfrom-failure (accessed 5 April 2016). 
This text is taken from The Three Sector Solution: Delivering public policy in collaboration with not-for-profits and business, edited by John Butcher and David Gilchrist, published 2016 by ANU Press, The Australian National University, Canberra, Australia. 